\title{
Sarcomatoid squamous cell carcinoma of pharynx: A case report with immunohistochemical study
}

\author{
Tadashi Terada* \\ Department of Pathology, Shizuoka City Shimizu Hospital, Shizuoka, Japan
}

Received: December 28, 2015

Accepted: January 29, 2016

Online Published: March 15, 2016

DOI: $10.5430 /$ crcp.v3n2p39

URL: http://dx.doi.org/10.5430/crcp.v3n2p39

\begin{abstract}
Primary sarcomatoid squamous cell carcinoma (S-SCC) of pharynx is a very rare tumor. A 77-year-old woman presented with sore throat. Laryngoscope revealed an infiltrating tumor of lower pharynx. The tumor was ulcerated and measured $3 \mathrm{~cm} \times 4 \mathrm{~cm}$ $\times 3 \mathrm{~cm}$. The tumor was invasive and involved the surrounding tissues. Biopsies showed sarcomatous malignant spindle cell proliferation as well as invasive well-differentiated squamous cell carcinoma (SCC). The former occupied $80 \%$ and the latter 20\%. Gradual transitions between malignant spindle cells and SCC were frequently seen. The histological diagnosis was S-SCC. Immunohistochemically (the results are shown in Table 1), the tumor cells were positive for vimentin, cytokeratin (CK) AE1/3, CK CAM5.2, CK WSS, CK KL-1, CK MNF-15, CK5, CK6, CK7, CK8, CK 18, CK19, p53 and Ki67 (labeling index = 65\%), but negative for CK34BE12, CK20, EMA, S100 protein, NSE, NCAM, synaptophysin, chromogranin, desmin, $\alpha$-smooth muscle actin, smooth muscle actin (HHF-35), h-caldemon, CD31, factor VIII-related antigen, CD34, HMB45, KIT, PDGFRA, CA19-9, CEA, bcl-2, CD3, CD20, CD45, CD138, myoglobin, HPV, and EBER. The author's diagnosis was S-SCC. The patient received chemotherapy and radiation, and is now in complete remission 3 years after the diagnosis.
\end{abstract}

Key Words: Pharynx, Sarcomatoid squamous cell carcinoma, Cytokeratin, Vimentin, Histopathology

\section{INTRODUCTION}

The vast majority of pharyngeal malignancy is squmaous cell carcinoma (SCC). The minority includes lymphoepithelial carcinoma, nasopharyngeal, adenosquamous, mucoepidermoid, adenoid cystic, pleomorphic, salivary duct carcinomas, and malignant lymphoma and any other sarcomas in Japan. ${ }^{[1-4]}$ Sarcomatoid carcinoma can occur in any organs, being particularly common in urinary bladder. ${ }^{[5,6]}$ Sarcomatoid carcinoma (also known as spindle cell carcinoma) of larynx is very rare, although over 100 cases have been reported as case reports or case series. ${ }^{[7-13]}$ About 3 years ago, the author experienced sarcomatoid squamous cell carcinoma (S-SCC) of pharynx.

\section{CASE REPORT}

A 77-year-old Japanese woman consulted our hospital because of sore throat, oral hemorrhage, and head pain. Laryngoscope revealed an infiltrating tumor of the lower pharynx. The tumor was ulcerated and measured $3 \mathrm{~cm} \times 4 \mathrm{~cm} \times 3 \mathrm{~cm}$. The tumor was very invasive and involved the surrounding tissues. Biopsy was taken from the tumor.

The biopsy showed features of invasive sarcomatous malignant spindle cell proliferation and of invasive welldifferentiated SCC, both of which were seen to be mixed up (see Figures 1 A-C). The areas of sarcomatous and SCC elements were $80 \%$ and $20 \%$, respectively. Gradual transitions or merges between the malignant spindle cells and

\footnotetext{
*Correspondence: Tadashi Terada; Email: piyo0111jp@yahoo.co.jp; Address: Department of Pathology, Shizuoka City Shimizu Hospital, Miyakami 1231 Shimizu-Ku, Shizuoka 424-8636, Japan.
} 
the SCC cells were seen (see Figure 1C). The spindle areas some of spindle cell areas showed epithelioid malignant cells. showed marked atypical features (see Figures 1 D-F), and The histological diagnosis was sarcomatoid SCC.
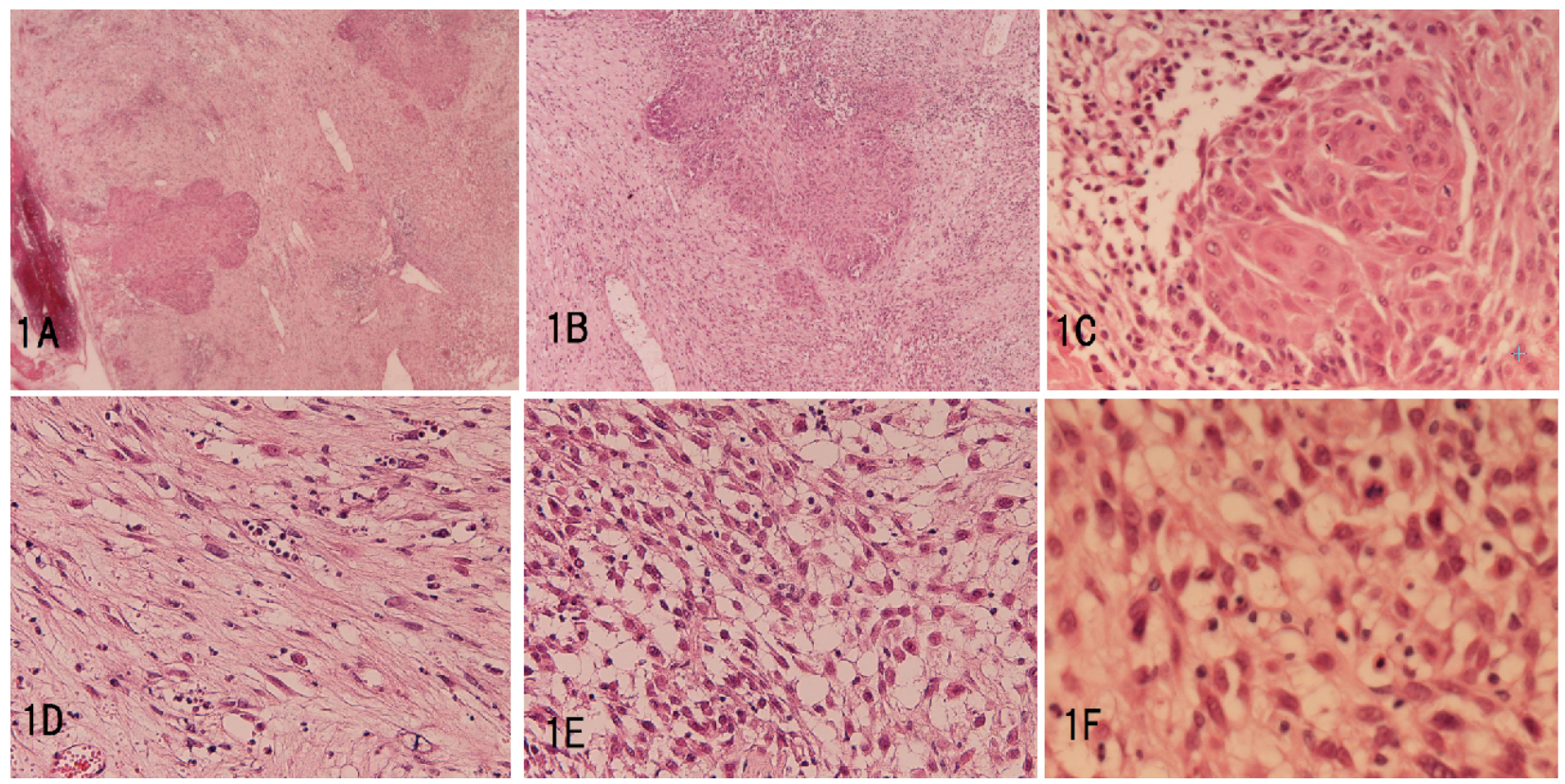

Figure 1. Histopathology of the pharyngeal tumor

A: Low-power view of the biosy. Atypical squamous epithelial cells and atypical mesenchymal tissue are seen. $H E, \times 20 ; B$ : Medium-size view of the squamous element. It shows invasive features and has significant atypia regarded as squamous cell carcinoma. HE, $\times 100$;

$C$ : High-power view of the squamous element. Invasive squamous cell carcinoma is apparent. There are gradual marges between squamous and sarcomatous elements; D,E: The sarcomatous element. The sarcomatous nature is apparent (D). However, focal epithelioid features are seen in some areas $(E)$. D,E: $\times 200 ; F:$ High-power view of the sarcomatous area. The cellular atypical features are prominent and they imply obvious malignant nature. $H E, \times 400$.
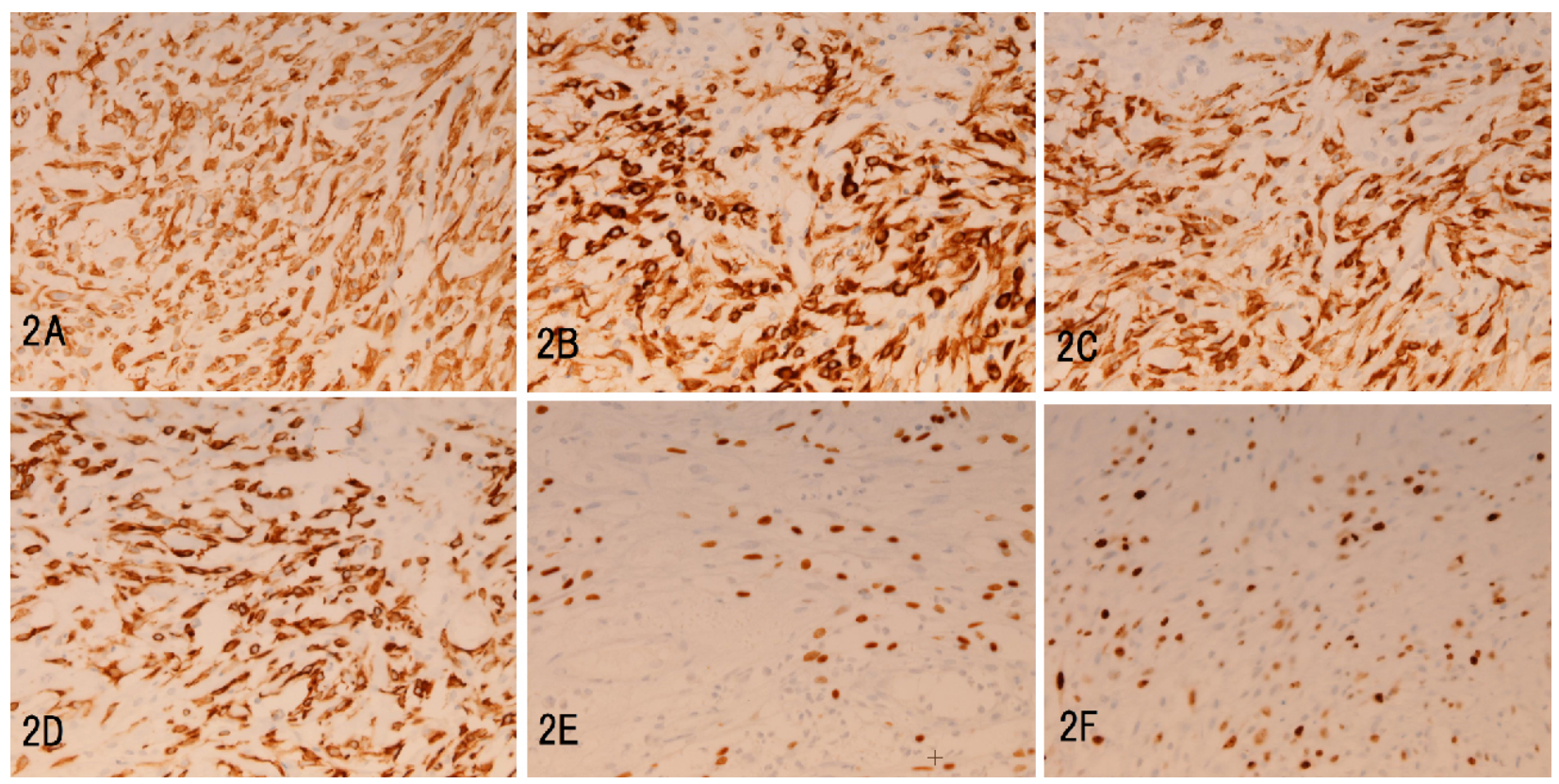

Figure 2. Immunohistochemistry of the pharyngeal tumor

The tumor cells were positive for vimentin (A), cytokeratin (CK) $5(B), C K 8(C), C K 18(D), p 53(E)$ and Ki-67 (F). A-F: $\times 200$. 
Table 1. Immunohistochemical results

\begin{tabular}{lll}
\hline Antigens & $\begin{array}{l}\text { Carcinomatous } \\
\text { element }\end{array}$ & $\begin{array}{l}\text { Sarcomatous } \\
\text { element }\end{array}$ \\
\hline Vimentin & + & +++ \\
CKAE1/AE3 & +++ & + \\
CKCAM5.2 & ++ & + \\
CK WSS & + & + - \\
CK KL-1 & ++ & + \\
CK MNF-15 & + & + - \\
CK5 & ++ & + - \\
CK6 & ++ & + - \\
CK7 & ++ & + - \\
CK8 & ++ & + \\
CK18 & ++ & + \\
CK19 & ++ & $+/-$ \\
CK34BE12 & - & - \\
CK20 & - & - \\
Tp53 & ++ & ++ \\
Ki67 & $65 \%$ & $70 \%$ \\
EMA & - & - \\
S100 protein & - & - \\
NSE & - & - \\
NCAM (CD56) & - & - \\
Synaptophysin & - & - \\
Chromogranin & - & - \\
Desmin & - & - \\
$\alpha$-smooth muscle actin & - & - \\
Muscle actin (HHF-35) & - & - \\
h-caldemon & - & - \\
CD31 & - & - \\
Factor 8 antigen & - & - \\
CD34 & - & - \\
HMB45 & - & - \\
KIT & - & - \\
PDGFRA & - & - \\
CA19-9 & - & - \\
CEA & - & - \\
bcl-2 & - & - \\
CD3 & - & - \\
CD20 & - & - \\
CD45 & - & - \\
CD138 & - & - \\
Myoglobin & - & - \\
HPV & - & - \\
EBER for EBV & - & - \\
\hline & - & - \\
\hline
\end{tabular}

An immunohistochemical study was performed with the use of Dako Envision technique as previously reported. ${ }^{[14]}$ Table 1 shows the results. The tumor cells were positive for vimentin (see Figure 2A), cytokeratin (CK) AE1/3, CK CAM5.2, CK WSS, CK KL-1, CK MNF-15, CK5 (see Figure 2B), CK6, CK7, CK8 (see Figure 2C), CK 18 (see Figure

Published by Sciedu Press
2D), CK19, p53 (see Figure 2E) and Ki67 (labeling index $=65 \%$ ) (see Figure 2F), but were negative for CK34BE12, CK20, EMA, S100 protein, NSE, NCAM, synaptophysin, chromogranin, desmin, $\alpha$-smooth muscle actin, smooth muscle actin (HHF-35), h-caldemon, CD31, factor VIII-related antigen, CD34, HMB45, KIT, PDGFRA, CA19-9, CEA, bcl-2, CD3, CD20, CD45, CD138, myoglobin, HPV, and EBER.

The author's diagnosis was sarcomatoid SCC. The patient received chemotherapy (cisplatin: total $700 \mathrm{mg}$, each day $30 \mathrm{mg} / \mathrm{m}^{2}$ for 20 days) and radiation (total 50 gray, each day 5 gray for 10 continuous days), and the patient is now in complete remission 3 years after the diagnosis.

\section{Discussion}

The present case is a very rare sarcomatoid (spindle cell) SCC of the pharynx. Approximately 100 cases of this tumor have been reported in nasopharyngeal locations. ${ }^{[7-13]}$ The diagnosis of the current tumor seems valid. The SCC component was invasive, and sarcomatous component expressed only vimentin and CKs. No other differentiations such as vascular, neurogenic, myogenic, lymphocytic, adenocarcinomatous, malanomatous, and neuroendocrine differentiations were observed. Thus, the sarcomatous element of the current case seem to have sarcomatoid carcinomatous features. Probably, the sarcomatous element seems to have arisen from SCC element. ${ }^{[12]}$

In the present tumor, the spindle cell sarcomatous element expressed CK and vimentin. Both the intermediate filaments were at first thought to be specific for epithelial cells and mesenchymal cells respectively, but this myth was broken. It is now accepted that some carcinomas express vimentin and some sarcomas CK. ${ }^{[15]}$ However, CK staining is more significant in the differential diagnostic pattern than vimentin staining. Thus, in tumors expressing both CK and vimentin, pathologists consider that these are more likely to be carcinomas than sarcomas if no other mesenchymal differentiations are seen. In the present case, the sarcomatous element showed only vimentin sparing other mesencymal markers. Thus, the present tumor was diagnosed as S-SCC. The presence of overt SCC element made the diagnosis certain.

A few decades ago, these tumors that show features of both carcinoma and sarcoma were categorized as carcinosarcoma. However, at present carcinosarcoma implies tumor having both distinct carcinoma and distinct sarcoma lineages where no transitions or merges between the two are seen. The present case is not carcinosarcoma because the sarcomatous element showed no differentiations and was not a distinct sarcoma. Frequent transitions or merges between SCC and 
sarcomatous elements were seen. Therefore, the current S-SCC

tumor is not carcinosarcoma but an S-SCC.

In East Asia, pharyngeal tumors are often associated with Epstein-Barr virus (EBV) and human papilloma virus (HPV). ${ }^{[16,17]}$ In the present tumor, EBV early RNA (EBER) was negative by in situ hybridization and HPV was negative in immunohistochemistry. These data suggest that neither EBV nor HPV are involved in the pathogenesis of the present

\section{REFERENCES}

[1] Sckolnick J, Murphy J, Hunt JL. Microsatellite instability in nasopharyngeal and lymphoepithelial carcinomas of the head and neck. Am J Surg Pathol. 2006; 30: 1250-3. PMid: 17001155. http: //dx.doi.org/10.1097/01.pas.0000209829.16607.cd

[2] El-Mofty SK, Lu DW. Prevalence of human papillomavirus type 16 DNA in squamous cell carcinoma of the palatine tonsil, and not the oral cavity, in young patients: a distinct clinicopathologic and molecular disease entity. Am J Surg Pathol. 2003; 27: 1463-1470. PMid: 14576481. http://dx.doi.org/10.1097/00000478-2 00311000-00010

[3] Chan JK, Suster S, Wenig BM, et al. Cytokeratin 20 immunoreactivity distinguishes Merkel cell (primary cutaneous neuroendocrine) carcinomas and salivary gland small cell carcinomas from small cell carcinomas of various sites. Am J Surg Pathol. 1997; 21: 226-34. PMid: 9042291. http://dx.doi.org/10.1097/00000478-199 702000-00014

[4] Terada T. Myoepithelial carcinoma of pharynx expressing KIT and PDGFRA. Int J Clin Exp Pathol. 2013; 6: 314-7. PMid: 23330018.

[5] Terada T. Spindle cell carcinoma progressed from transitional cell carcinoma of the urinary bladder. Int J Clin Exp Pathol. 2012; 5: 83-8. PMid: 22295151.

[6] Terada T. Sarcomatoid carcinoma of the urinary bladder: a case report with immunohistochemical and molecular genetic analysis. Med Oncol. 2010; 27: 547-53. PMid: 19521796. http://dx.doi.org /10.1007/s12032-009-9247-3

[7] Jagtap SV, Shukla DB, Jagtap SS, et al. Sarcomatoid (spindle cell) carcinoma of the cricopharynx presenting as dysphagia. Indian Journal of Basic and Applied Medical Research. 2014; 4: 176-80.

[8] Su HH, Chu ST, Hou YY, et al. Spindle cell carcinoma of the oral cavity and orolarynx: factors affecting outcome. J Chin Med Assoc. 2006; 69: 478-83. http://dx.doi .org/10.1016/S1726-4 901 (09) 70312-0

[9] Anupam S, Rajjyoti DJD, Sharma AC, et al. Spindle cell carcinoma of the head and neck: A clinicopathological and immunohistochemical study of 40 cases. Journal of Cancer Therapy. 2012; 3: 1055-9. http://dx.doi.org/10.4236/jct.2012.36137

\section{Conclusion}

The author presented a rare case of sarcomatoid (spindle cell) SCC of pharynx. The tumor was not associated with EBV and HPV.

\section{CONFlicts OF INTEREST Disclosure}

The author has no conflict of interest.

[10] Leventon GS, Evans HL. Sarcomatoid squamous cell carcinoma of the mucous membranes of the head and neck: a clinicopathologic study of 20 cases. Cancer. 1981; 48: 9941003. http://dx.doi.org/10.1002/1097-0142(19810815) 4 $8: 4<994::$ AID-CNCR2820480424>3.0.CO;2-M

[11] Ansari MA, Hoque MO, Califano J, et al. Immunohistochemical p53 expression patterns in sarcomatoid carcinomas of the upper respiratory tract. Am J Surg Pathol. 2002; 26: 1024-31. http: //dx.doi.org/10.1097/00000478-200208000-00007

[12] Choi HR, Sturgis EM, Rosenthal DI, et al. Sarcomatoid carcinoma of the head and neck: molecular evidence for evolution and progression from conventional squamous cell carcinomas. Am J Surg Pathol 2003; 27: 1216-20. PMid: 12960805. http://dx.doi.org/10.10 97/00000478-200309000-00004

[13] Lewis JE, Olsen KD, Sebo TJ. Spindle cell carcinoma of the larynx: review of 26 cases including DNA content and immunohistochemistry. Hum Pathol. 1997; 28: 664-73. http://dx.doi .org/10.10 16/S0046-8177 (97) 90175-1

[14] Terada T, Kawaguchi M, Furukawa K, et al. Minute mixed ductalendocrine carcinoma of the pancreas with predominant intraductal growth. Pathol Int. 2002; 52: 740-6. PMid: 12685552. http: //dx.doi.org/10.1046/j.1440-1827.2002.01416.x

[15] Skinnider BF, Folpe AL, Hennigar RA, et al. Distribution of cytokeratins and vimentin in adult renal neoplasms and normal renal tissue: potential utility of a cytokeratin antibody panel in the differential diagnosis of renal tumors. Am J Surg Pathol. 2005; 29: 747-4. PMid: 15897741. http://dx.doi.org/10.1097/01.pas.0000 163362.78475 .63

[16] Tsao SW, Tsang CM, Pang PS, et al. The biology of EBV infection in human epithelial cells. Semin Cancer Biol. 2012; 22: 137-43. PMid: 22497025. http://dx.doi.org/10.1016/j.semcancer. 2012. 02.004

[17] Agoston ES, Robinson SJ, Mehra KK, et al. Polymerase chain reaction detection of HPV in squamous carcinoma of the oropharynx. Am J Clin Pathol. 2010; 134: 36-41. http://dx.doi .org/10.13 09/AJCP1AAWXE5JJCLZ 